\title{
RENEWAL OF LEGAL POLITICS OF INTERNATIONAL AGREEMENTS CONCERNING INDONESIA'S LOAN AGREEMENT TO ACHIEVE SUSTAINABLE DEVELOPMENT
}

\author{
Siti Sumartini \\ Faculty of Law, Universitas Wiralodra \\ E-mail: sitisumartini_unwir@yahoo.co.id
}

\begin{abstract}
The government loan agreement is a tool or mechanism to generate capital, and as a source of national development financing as set forth in the $R A P B N$ framework. However, it is practically reviewed that the status of the foreign loan agreement is inconsistent with the existing laws and regulations, particularly Law Number 24 of 2000 on International Agreement (Treaty). In the provisions of the law, foreign borrowing is one aspect that is subject to the criteria as an international agreement, whereas in the implementation of the $G$ to $G$ government loan agreement tends to use the international private legal system. In addition, loan agreement clauses often do not accommodate the debtor country's interest in realizing sustainable development. Therefore, a renewal on legal politics related to the loan agreement is required to fulfill the legal certainty element, and it can accommodate the national interest.
\end{abstract}

Keywords: loan agreement, legal politics, and sustainable development

\section{A. INTRODUCTION}

Development is a systematic and planned effort by each and all components of the nation to transform a situation into a better state by utilizing the available resources optimally, effectively, efficiently and accountably, so as to improve the quality of life of the community to be more prosperous. The understanding of the National Development is an effort implemented by all components of the nation in order to achieve the goals of the state. National Development itself is organized based on democracy with the principles of togetherness, fairness, sustainability, environmental insight, and independence by maintaining the balance of progress and national unity (Article 1, Paragraph (2) of Law Number 25 of 2004 on The National Development Planning System).

In the context of national development, long-term development planning is needed as the overall direction and priority of development which will be carried out in stages to create a just and prosperous society as mandated by the 1945 Constitution of the Republic of Indonesia. It is an elaboration of the purpose of the establishment of the Government of Indonesia contained in the Preamble of the 1945 Constitution of the State of the Republic of Indonesia, which is to protect the whole nation and the entire blood of Indonesia, to promote the common

Yustisia Vol. 7 No. 1 January - April 2018

Renewal of Legal Politics of International... 
prosperity, to educate the life of the nation, and to carry out the world order based on freedom, eternal peace and social justice in the formulation of vision, mission and direction of National Development (Article 3 of Law Number 17 of 2007 on The National Long-Term Development Plan 2005-2025). It is understandable that the national development that is being run by the Government of Indonesia is a macro development and should have the character of sustainable development.

Implementation of the government to realize the purpose of the state raises the rights and obligations of the state that can be assessed with money (Preamble, point (a) Law Number17 of 2003 on The State Finances). State finance is managed in an orderly, law abiding, efficient, economical, effective, transparent and accountable manner regarding the sense of justice and propriety (Article 3 Paragraph (1) of Law Number 17 of 2003 on The State Finances). In essence, the state is a political institution. In such a position, the state is subject to the order of public law. Through the activities of various government agencies, the state seeks to provide welfare state (Hata, 2006: 28).

The state as a public legal entity can perform legal acts aiming to realize social justice for the people of Indonesia as a consequence of the modern welfare state (Sjahrudin Rasul, 2011). Building a strong state will require the accumulation of wealth and capital and therefore economic development must be prioritized. ${ }^{1}$ To develop the state the Government, of course, requires financing. The financing is certainly within the framework of the State Budget (APBN) (Analisis Kebijakan Pemanfaatan Pinjaman Luar Negeri Pemerintah; Kementerian Perencanaan Pembangunan Nasional/Badan Perencanaan Pembangunan Nasional, December 2015: 348). If the accumulation of financing is not sufficiently done in the state, it can be done, among others, by increasing international trade and loan agreement. Also it can affect the economy of the state. Loan agreement in support of national development is influenced by government policy in utilizing foreign loans. In addition, foreign loans are not only intended to cover the financing gap, but also implemented within the framework of development cooperation (Muhammad Djafar Saidi, 2010).

Almost all developing countries still depend in economy on developed countries and foreign loan is the main choice due to their economical backwardness. Although tax burden can also be used as an alternative in the effort to bring capital to the country, the loan agreement is considered to be a more suitable alternative because it is considered not too burdensome people than when using the mechanism of tax imposition on the people (Sri Setianingsih Suwardi, 1995: 74). 
In its development, the need for foreign debt not only is defined in economic space, but also has begun to penetrate into the political dimension. It is common that foreign debt policy is used as one of the bargaining power owned by creditor countries (generally developed countries) to expand their foreign policy based on their respective self-interest on the countries as the borrower or the debtor (in this case usually the developing countries) (Eddy Pratomo, 2011: 1). In fact, from a broader perspective foreigners have various motivations behind the loan assistance it provides. For example, during the cold war, ongoing financial aid from western countries accepted by developing countries is intended to prevent the influence communists in the latter's regions (H.M Said Nisar, 2008: 292293).

In this era of globalization, interaction and intensity of relations between countries have been increasing and they are marked, among others, by the achievement of various agreements of bilateral, regional and multilateral cooperation. Such agreements are commonly embodied in a form of international agreements covering various fields including politics, economics, commerce, law, defense, socio-culture and so on. Even the existence of international cooperation in various forms and types is always dominated by economic issues. Therefore, according to Jackson, head spinning (coil) of all international networks always lies in economic issues. Thus any form that is used in international cooperation is part of a government's policy of a country to launch its economic strategy across state boundaries (Damos Dumoli Agusman, 2010: 2-3).Economic issues and international law are two subjects that have a convergence relationship, which implies that the economic issue is a central point in the life of the nation and is therefore considered to be the frame of nations ((Damos Dumoli Agusman, 2010: 2$3)$.

The complex of international agreements by Indonesia with other international legal subjects (countries or international organizations) has also colored the development of law of international agreement in both practical and theoretical terms. This fundamental change along with the increasingly unfamiliar character of international association has the potential to rise to transnational problems in the field of law ((Damos Dumoli Agusman, 2010: 14). Likewise Indonesia cannot escape from these fundamental changes and even experience the process of pressure and demands within the country, namely the existence of a demand for legal certainty in all fields including the relationship between international and national laws and the implementation of international law into 
the national legal system (http://ekbis.sindonews.com/read/994988/33/ini-penjelasanbi-soal-utang-ri-ke-imf-1430225454 accessed on April 14 $\left.{ }^{\text {th }}, 2017\right)$.

As for the loan agreement, various forms of agreements have been made either between a country and international organizations such as the World Bank, between one country and one or more countries or between one country and the foreign private sector. The mechanism of such a diverse form of agreement has, of course, also led to different legal consequences. Through the history, the number of irregularities on foreign loan agreements that have brought Indonesia into an economic recession and its peak requires President Suharto to sign a letter of intent with the IMF (This has been explained by Peter Jacobs as Director of Communication Department of Bank of Indonesia (BI) http://finance.detik.com accessed on April 14 ${ }^{\text {th }}, 2016$ ). Indonesia's debt to the IMF in 1998, is to meet the needs of the balance of payments that eroded due to the economic crisis in Indonesia (Syahmin AK, 2006: 117). This has a negative impact on the subsequent growth of the Indonesian economy, especially the burden on state finances. Besides, the IMF program is too much to interfere with the sovereignty of the state it helps. However, after nearly two decades the debt can finally be repaid in 2006 (Documents Compilation of the International Treaties (Compilation of International Agreement Manuscript registered at Economic and socio-Cultural Agreement Room, Directorate General of Law and International Agreement of the Ministry of Foreign Affairs) 2008: 343).

Unlike the World Bank which are more hinted to use public international law in performing loan agreements, in engaging in bilateral foreign loan on a practical level, Government of Indonesia is more likely to use international civil law. In this case, one of the parties uses the national law of the creditor country. Such example is loan agreements that have been made by the Government of Indonesia with some countries using various nomenclatures such as the use of the term "Arrangement" between the Government of the Republic of Indonesia and the Republic of Korea dated 17 November 2007 in the case of Indonesia's development financing assistance. Another example is the nomenclature of "Agreement" between the Government of the Republic of Indonesia and the Government of the Federal Republic of Germany on Financial Cooperation (Sumber Bagian Hukum dan Perjanjian Internasional (Treaty Room)Divisi Ekonomi, Sosial dan Budaya Kementeriann Luar Negeri Republik Indonesia, Jakarta). Then "The Exchange of Notes" between the Government of the Republic of Indonesia and the Government of Japan dated March 10, 2011 for the financing of Indonesia's infrastructure development of Phase III (Himpunan Naskah Perjanjian Internasional Yang Telah Ditandatangani Oleh Pemerintah RI Vol I, Number2001.1.2001 Tahun 2001 Periode Januari-Desember, Dirjenn Ekososbud Departemen Luar Negeri). 
Some loan agreements mentioned above are the foreign loan agreements of the Government of Indonesia with other countries which are regulated not by using international legal mechanism but rather by using one of the provisions of the national law of the parties namely the national law of the country providing loans as a creditor country (Damos Dumoli, 2010: 14). In addition to the legal options (in this case usually the law of the donor / creditor country), in some loan agreements the government also contains clauses that are disproportionate to Indonesia and do not contribute to Indonesia's development. An example is the covenant documents made between the Government of the Republic of Indonesia and other countries (Huala Adolf, 2010: 60-61).

According to observers of the international agreement of Damos Dumoli, the loan agreement is, in conventional terms, an international civil agreement and is subject to certain national laws so that the status of which is not an international agreement "Governed by International Law", and thus not an international agreement as intended by the Vienna Convention of 1969 on the International Agreement and the Law Number 24 of 2000 on the International Agreement (Damos Dumoli, 2010: 26). Similarly, several other scholars consider that the loan agreements, as commercial agreements, are equivalent to an international contract (https://thelawdictionary.org/loan-agreement/ accessed on April 20 $0^{\text {th }}, 2015$ )

On the other hand, there are still many loan agreements as well as other commercial agreements that do not explicitly mention governing law so that the status of the agreement is submitted to the interpretation in the future when there is a dispute between the parties (Otje Salman dan Anthon F Susanto, 2009: 15).

The definition of loan agreement according to Black's Law Dictionary is (Mochtar Kusumaatmadja, 2006: 10):

"Formal document, the signed contract, evidences a loan. Negative and positive covenants, guaranties, financial reporting requirements, applicable interest rate and fees, and how the loan will be repaid and over what period, type and value of the collateral pledged, are some of the parts and inclusions to a loan agreement."

Whereas, foreign loan agreement, according to Government Regulation (PP) Number10 of 2011 on Procedures of Procurement of Foreign Loans and Acceptance of Grants in Article 1 Paragraph (6), is described as follows:

"The Foreign Loan Agreement is a written agreement on the loan between the Government and the Foreign Lenders."

The above explanation necessarily requires a deeper review because there is no inconsistency between the prevailing laws and the practice run by the Indonesian Government over the implementation of the loan agreements with 
other countries ( $G$ to $G$ ). Such conditions can certainly have an impact on the Indonesian legal system, especially on the legal certainty aspects of the national legal system and the inability to perceive the legal function for the development that is being carried out. Some of the reasons behind the analysis are in terms of both national and international law.

\section{B. PROBLEM STATEMENT}

Based on the above explanations, the problems in this article are focused on:

1. What is the status of loan agreements between the Indonesian Government's and other countries, reviewed theoretically and practically in the Indonesian legal system?

2. How does the legal politics of international loan meet the loan agreements between the Government of Indonesia and other countries to realize sustainable development?

\section{RESEARCH METHODS}

Based on the data that used and the nature of the juridical-normative research in this research applied statute approach. Data analysis conducted in qualitative technique by legal interpretation and synchronization of the provisions of the related acts. Data gathering collected by library research to select the important part of Act on the legal politics of international loan.

\section{DISCUSSION AND RESEARCH RESULT}

Cf Louis, quoted in Otje Salman and Anthon F Susanto, explains that the law is essentially a living organism, whose vitality depends upon reneval containing ideal function, such as elements ofmorality (zedelik element) and rationality (verstandelik lement van het recht). Both are ideal elements of the law as well as show the real function of the law, namely: elements of human and society, environment, and tradition (Atip Latipulhayat,.( Khazanah Mochtar Kusumaatmadja),Padjadjaran, December 2014: 628-629). Meanwhile, in a country that is establishing the law to have a very important role, it will be indispensable for the contribution of the law as a social principle whose method will not be separated from the question of value a society. In other words, good law is the values prevailing in society and they should be owned by a developing society. Thus, the essence of development is a matter of renewing the way of thinking and attitude that is alive.

Furthermore, in the Theory of Development Law, Mochtar explains that developing societies are characterized by change. However, we define that whatever measure we use in a development society, the role of law in it is to ensure that change occurs regularly (Damos Dumoli Agusman, 2010: 24). Since the 
essence of development is change, when the law must play its part, it cannot be understood as a static element that always lies behind the change itself; the law must be ahead in guarding the change. Law is not only a follower, but it must be the prime mover of development. At this point Mochtar explicitly uses the term law as a means of renewal of society (Samantha Besson and John Tasioulas, 2010: 9).

National development has always prioritized the field of economy. Development in the economic sector is a fundamental development for the realization of social welfare and justice for all people. This is mandated by the 1945 Constitution of the State of the Republic of Indonesia, which is further explained in Article 33 paragraph (4): the national economy is organized based on economic democracy with the principle of togetherness, efficiency, equity, sustainability, environment, independence and balancing progress and national economic unity. Obviously this can be a reference for the government in making foreign loan agreements overseas with other countries.

\section{Status of the Government of Indonesia's Foreign Loan Agreements with Other Countries, Theoretically and Practically Reviewed in Indonesian Legal System.}

The international treaty is one of the best known sources of international law today governing state relations in its written form. As with any contract, international treaties bind these States as parties to an international treaty, in which the parties are meant to be bound by their rights and duties imposed by an international treaty. It is further explained that "treaties include specifics or may be framework treaties, spelling acceptantives and principles. Some treaties require regular meetings also towards parties, in order to make decision about treaty implementation. Also designate supervisory bodies to monitor compliance with the treaty." (Huala Adolf, 2011: 2)

The international treaty is also regarded as an instrument that gives rise to the norms of concrete international obligations in international law, due to the understanding that international law is a general and abstract law. Consequently, the role of international treaties positively contributes to the existence of international law today. This is explained as follows "the nature of the norms that are referred to as international law, and more particularly the absence of general and abstract rules in international law. International norms are often thought to stem exclusively from bilateral agreements between states and to create relative and concrete obligations." (Wolfgang Friedman, 1953: 89). The international agreements are largely characterized by the increasing interdependence of the world economy. This dependence is due to the variety of natural resources or other dominant factors, such as population, technology, and economic aspects 
between one country and another (http://treaty.kemlu.go.id/aboutus/info/about_treaty_room, Directorate of Law and International Agreement of the Ministry of Foreign Affairs, accessed on January $20^{\text {th }}, 2018$ ).

In the development of international treaties as sources of international law there are also other forms of transnational agreements which practically have two different types, namely international treaties subject to public law and international agreements subject to the system international civil law (i.e. international contract). Through the history, it has long been a habit for statesmen to use the rules of law governing the contractual relationship both between individual to individuals and between country to country in international agreements. Wolfgang Friedman explains that besides the international treaties, there are several international agreements whose existence complements the treaty. More complete explanation can be described as follows (Eddy Pratomo, 2009: 2:

" A new type of international transaction somewhere between the traditional spheres of public and private international law has gained increasing acceptance, it is best described as "international agreements", we must accept these international agreements other than treaties as additional source of public international law, because they concern and affect public international relations. It is to such international agreements as the international loan transaction concluded between World Bank and variety of governments or Private Corporation."

Since Indonesian Independence Day until now there have been thousands of agreementsmade and followed by Indonesia both with friendly countries and with other international legal subjects whether ratified or not ratified (Article 10, Point (e) of Law Number 24 of 2000 on The International Agreement). However, in practice, many of the agreements that have been made experience confusion (distortion) of understanding and this is due to inadequate knowledge of international treaties (Syahmin AK, 2006: 117). It is also experienced by Indonesia in making the loan agreement showing the government's inconsistency with the existing provisions of Law Number 24 of 2000 on International Agreement which has placed agreements on foreign loans and grants. Thus the loan agreement under this law has a public character as well as other international agreements (Source of Division of Law International Agreement (Treaty Room), Economic, SocioCultural Division, the Ministry of Foreign Affairs of the Republic of Indonesia, Jakarta) 
Unlike the World Bank which are more hinted to use public international law in performing loan agreements (Damos Dumoli, 2010: 14), in engaging in bilateral foreign loan on a practical level, Government of Indonesia is more likely to use international civil law. In this case, one of the parties uses the national law of the creditor country (Huala Adolf, 2010: 60-61).

According to observers of the international agreement of Damos Dumoli, the loan agreement is, in conventional terms, an international civil agreement and is subject to certain national laws so that the status of which is not an international agreement "Governed by International Law", and thus not an international agreement as intended by the Vienna Convention of 1969 on the International Agreement and the Law Number 24 of 2000 on the International Agreement (Damos Dumoli, 2010: 26). Similarly, several other scholars consider that the loan agreements, as commercial agreements, are equivalent to an international contract (Damos Dumoli Agusman, 2008: 22). On the other hand, there are still many loan agreements as well as other commercial agreements that do not explicitly mention governing law so that the status of the agreement is submitted to the interpretation in the future when there is a dispute between the parties (Damos Dumoli Agusman, 2010: 14-17).

In its development, the status and position of the foreign loan agreement in the Draft of Law on Foreign Loan and Grant Agreement which is still hanging up, raise a discourse to differentiate the loan agreement into two types namely the agreement governed by international law and the agreement governed by national law. The logical consequence is that the former enacted Law Number24 of 2000 on International Agreements, while the latter did not (Eddy Pratomo, 2008: 89).

The thing to remember and require a thorough assessment of the government's loan agreements is that government foreign loan is a form of agreement that has great consequences and impacts in the financial and economic sustainability of the country, and will also have an impact for generations to come (Government Regulation of the Republic of Indonesia Number 2 of 2006 on Procedures of Procurement of Loan and/or Acceptance of Grants). Likewise the status and position of the government's foreign loan agreement to be immediately enacted, since the lack of clarity on the status and position of the government's foreign loan agreement will create legal uncertainty. Furthermore, it is emphasized that Eddy Pratomo's view of uncertainty about the theory or understanding shared by a state can result in unclear compliance of a state in carrying out its international obligations, that is by applying the international treaty norms it has agreed upon (Profil Utang dan Penjaminan Pemerintah Pusat Edition April 2017 Directorate General 
of Financing and Risk Management of the Ministry of Finance of the Republic of Indonesia).

Foreign loan agreements, viewed in terms of requirements, can be divided into (Daud Silalahi, 2014: 8):

a. Concessional Loan, which is the Government's foreign loan in the framework of financing development projects. Official Development Assistance (ODA) soft loans, both bilateral and multilateral;

b. Semi-concessional loans, which are similar to the use of soft loans, are much heavier than soft loans but are lighter than commercial loans;

c. Commercial Loan, which is a loan received under the conditions of the money market and international capital markets. This loan is also commonly called cash loan.

The current Indonesian government debt based on the latest data the author obtained on April 2017 was Rp3, 667.41 trillion, consisting of Government Securities (SBN) of Rp2, 932.69 trillion (80 \%) and loans of Rp.734.71 trillion (20\%). The increase in net debt during April 2017 of Rp16.37 trillion came from the issuance of SBN (net) of Rp19.85 trillion and a decrease in net loan of Rp3.49 trillion. Payments on debt obligations in April 2017 was Rp 49.23 trillion, consisting of principal payments of Rp 38.46 trillion and debt interest payment of Rp10.77 trillion (http://www.pelangi.or.id/article-13-.html World Summit on Sustainable Development, accessed on January $\left.14^{\text {th }}, 2016\right)$.

\section{Adequate Legal Politics of International Agreement on the Government of Indonesia's Foreign Loan Agreement with Other Countries to Achieve Sustainable Development}

Sustainable and environmental development, or the principle of sustainable, as it called in an academic perspective, is a definition suggested by Brutland Report in 1987: "Sustainable development is development that meets the needs of present without compromising the ability of future generations to meet their own needs" (Daud Silalahi, 2008) meaning: "Pembangunan berkelanjutan adalah pembangunan untuk memenuhi kebutuhan masa sekarang tanpa mengurangi kemampuan generasi mendatang dalam memenuhi kebutuhannya." (Nico Schrivjer dan Fiedl Weiss, 2004: xi). The principle of sustainability refers to development which includes good social, economic and environmental development (Marc Williams, Aid Sustainable Development and The Environmetal Crisis, Int'l Journal of Peace Studies http://www.gmu.edu/programs/icar/ijps/vol3_2/Williams.htm accessed on 
May $30^{\text {th }}$, 2017). In particular, Nico Schrivjer and Fiedl Weiss described aspects of sustainable development as follows:

"However, sustainable development, at least as a concept, is not going to disappear from sight, as these mentioned concepts have. On the contrary, it can be confidently predicted that sustainable development will remain with us because, clearly, it has already successfully established its credentials, both as an idea and as a legal concept in law" (Koesnadi Hardjasoemantri, 2003: 10-11)

The above opinion is reinforced by some basic thoughts of the emergence of sustainable development for several reasons (Sudikno, 2010: 56):

"First, sustainable development appears to require an inescapable commitment to equity, specifically inter-generational equity. In other words, sustainable development policies should ensure that the welfare of future generations is no lower than our own. Secondly, sustainable development requires an entrenchment of environmental considerations in policy-making. Efficiency in resource use entails the internalization of environmental costs in pricing decisions. That is, efficiency is defined so that the full costs of goods and services are reflected in the price of production inputs and consumer goods. Thirdly, there is concern with the inter-country and intracountry effects of changes in economic policies."

From the above explanation, there are three reasons for the concept of sustainable development. First, sustainable development seems to require an unavoidable commitment to justice, especially intergenerational justice. In other words, sustainable development policies must ensure that the well-being of future generations may not be lower than that of us today. Second, sustainable development requires deep consideration of environmental policy, efficiency in the use of natural resources, as well as on financing which, in this case, is efficiency of financing of production and consumer goods. The last one is the concern about the impact of changing relations between two countries or within two parties in a country on economic policy.

In line with this, Indonesia's commitment to sustainable development principles has also been realized by incorporating the principle into the 1993 State Policy Guidelines influenced by the United Nation Rio Declaration of Environment and Development (1992), which explains that sustainable development is always a national policy (Yudha Bhakti, 2012: 1-2). Therefore, the loan agreement of the government should be reviewed in terms of its status and position. To realize a sustainable development, it requires legal politics of the government in putting the government loan agreement into a proportional mechanism accommodating the principle of sustainable development. 
Either from the perspective of international treaty law or from its implementation concerning Indonesia as a party to the loan agreement, the process of examining the legal politics related to the government's loan agreement is a process in the context of legal discovery, broadly defined, both within the institution of the author and in the sphere of understanding. According to Sudikno, the discovery of the law, in a broader sense, may include not only the implementation of law, but also the establishment of law as well as the creation of law (Iman Syaukani, A Ahsin Thohari, 2010: 21-22). In addition, the element of legal discovery can also be found in various arrangements of the law institution in the form of procedural law and material law, or it can be found in various international legal instruments in the form of conventions or international agreements (Abdul Hakim Garuda Nusantara, 1985).

The legal politics in theoretical study can be found in various opinions of experts in the Dutch dictionary written by van der Taas suggesting that politiek contains beleid meaning. The word beleid means policy. In other words, legal politics means legal policy (David M Trubek, 2006: 5).

Legal politics, in the broad sense, includes the process of making and enforcing laws that can indicate the nature and direction to which the law will be established and enforced (Profil Utang Pemerintah Pusat; Kementerian Keuangan Republik Indonesia; Ditjen Pengelolaan Pembiayaan dan Resiko; Edisi April 2016, pp.6.). The final process of a legal politics is the enforceability of the law within the community or in the life of the nation and the state, then evaluation of the implementation of the law is a matter of law enforcement which will give good results when it is managed well.

Through the legal policy (legal politics) of the government that accommodates the principle of sustainable development, it is expected that the loan agreement that has been done by the government with other countries will have a positive impact for the creation of fiscal sustainability and the realization of the welfare state. The legal politics of the government's foreign loan agreement should be done by prioritizing the precautionary principles as a value, the principle first emerging in the field of environmental protection. The reason is that the principle of prudence can also be applied by every decision maker and is a policy in the life of Indonesian statehood. It is also reinforced by an interpretation. The Precautionary principle is interpreted in accordance with Principle 15 of UNCED.

On the other hand, the importance of legal aspects in making a positive contribution to the development of a country's economic field is explained by Trubek as follows: 
The primary use of law in the developmental state is as a tool to remove "traditional" barriers and change economic behavior. Laws are needed to create the formal structure for macroeconomic control. Legislation can translate policy goals into action by channeling economic behavior in accordance with national plans. (The Preamble of Law Number 37 of 1999 on The Foreign Relation)

It is understood that the use of legal aspects especially in developing countries is a tool to remove the barriers that are "traditional" and can change the behavior of the economy. Legal aspects are needed to create a formal structure for macroeconomic control. Legislation, in this case, can translate policy objectives into action (implementation) by providing space for economic behavior to conform to national plans.

The implementation of the legal aspect as a means or tool in making economic change must be reflected in the principles of good governance in conducting the governance of state finances to realize sustainable development. Some Principles of Good Governance to be considered in terms of management of debts or loans in general and the government's loan agreements in particular are (Damos Dumoli Agusman, 2010: 26):

1) Procurement / issuance of debt through APBN mechanism / obtaining Parliamentary approval;

2) Government Coordination (Ministry of Finance, Ministry of PPN / Bappenas), and Bank of Indonesia in the planning and management of debt;

3) Accountability of debt management and publication of data and information on debt.

The description of the above description can be illustrated through a scheme related to the legal politics of the loan agreement of the government that can realize the welfare state as follows:

Scheme of the relationship between the Legal Politics of the Loan Agreement and the realization of Welfare State

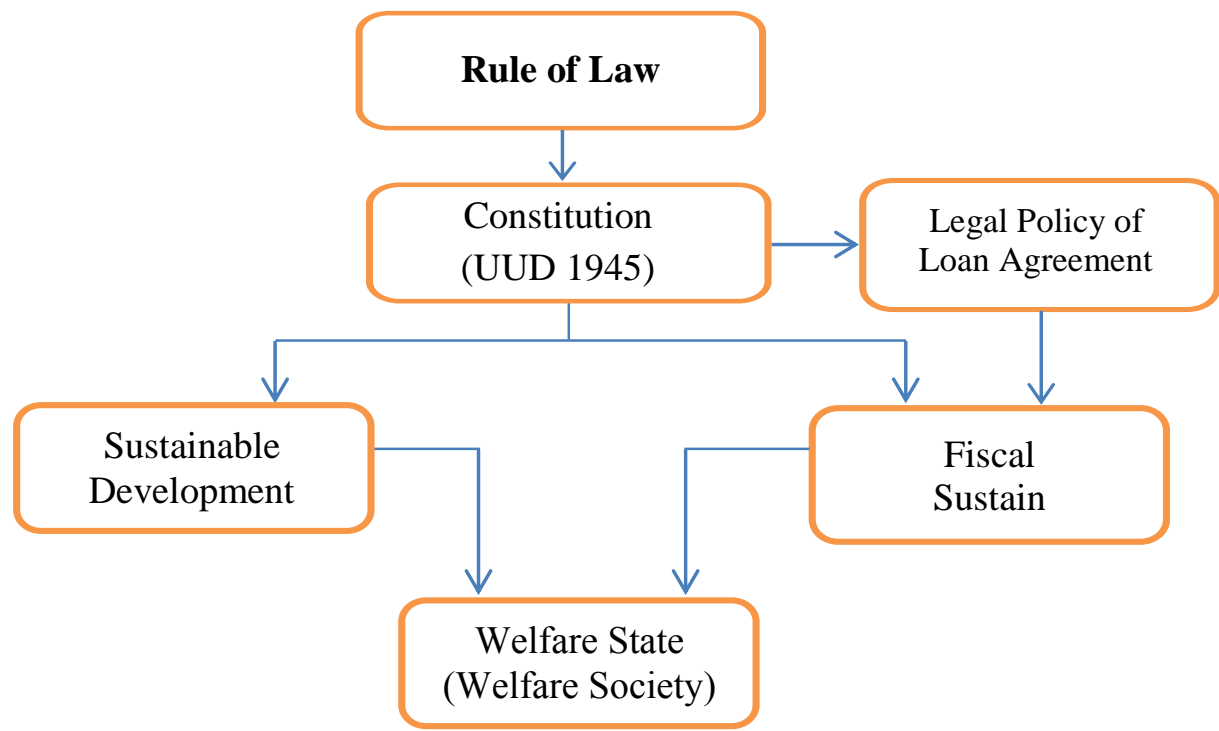


Efforts that can be made by the government in order to build a legal politics on the loan agreement is to choose an international agreement mechanism that can contribute to the sustainable development. Establishment and implementation of foreign loan agreements should consider that international cooperation is done for the sake national interests (Huala Adolf, 2010: 5). Instead of international law through international agreement, mechanism is preferred to accommodate both parties in exercising their rights and obligations. This is so because:

1. The legal subject of a loan agreement is, in the perspective of international law, a public entity; and the political interests of the state and its position as a sovereign state are to realize the welfare of its people. Therefore, the state acts in the quality of iure imperii (public quality) (Damos Dumoli Agusman http://perjanjianinternasional.blogspot.com/p/oleh-damos-dumoli-agusman-apaperbedaan.html accessed on May $\left.07^{\text {th }}, 2016\right)$. In other words, the position of the parties is as the subject of international law;

2. Today, the loan agreements between the parties referred above often tends to require that it is not subject to the national jurisdiction of one of the Contracting States. Thus, in this case, international law regulates agreements between parties in this constellation, then the parties consciously position themselves in balance before international law (Article 11 Paragraphs (1) and (2) of Law 17 of 2003 in conjunction with Article 8 Paragraph (1) and 3(3) of Government Regulation 10 of 2011 on The Procedures of Procurement of Foreign Loans and Acceptance of Grants). This is because international law is a neutral. On the other hand, a weakness in the use of an international civil legal system on a government loan agreement of a country is that it can complicate the parties if there is a dispute between them, especially in the law and forum selection, because a country rarely submits, by voluntarily, to a foreign judicial body. This is because it involves the question of the sovereignty and immunity of a country; and the use of such national laws is somewhat unknown to others $(\mathrm{H}$. M Said Nisar, 2008: 302).

3. On the other hand, some countries, like Germany, and donors, like the International Fund for Agriculture Development also want the loan agreements to take the form of international agreements that are subject to the Vienna Convention of 1969, and this is further emphasized IBRD / IDA Article 10.01 GC IBRD / IDA stating that a loan agreement between the IBRD / IDA and the debtor country in 
its legal arrangement regardless of the national legal domain of any country is subject to international law (Damos Dumoli Agusman http://perjanjian-internasional.blogspot.com/p/oleh-damos-dumoli-

agusman-apa-perbedaan.html accessed on May $07^{\text {th }}, 2016$ );

4. The 1945 Constitution in Article 11 paragraph (2) explains that international agreements which have broad and fundamental consequences for people's lives related to the financial burden of the state must obtain the approval of Parliament. However, according to the author, "approval" in the making of the government's foreign loan agreement is understood as a prior approval that has been inherent in approval of RAPBN each year (Article 11 Paragraphs (1) and (2) Law Number 17 of 2003 on The Procedures of Procurement of Foreign Loans and Acceptance of Grants).

5. Law Number24 of 2000 on the International Treaty (as an organic law), Article 10 letter (f) includes loan agreement as one of treaties which are subject to the provisions of an international agreement. The reason for the introduction of a loan agreement into the law is that it concerns the political psychological aspect that the loan agreements have the potential to burden the state's finances and have an impact on the broader society not only perceived at the time of the treaty made but also for the foreseeable future, especially in the case of Indonesian state debt repayment. This is certainly closely related to the principles of sustainable development.

Another important thing is the opinion of Said Nisar suggesting that the aspect of international relations in the framework of international cooperation is a fundamental need that cannot be separated from the life of the nation and the state for no country can meet its own needs. However, this need must be understood and accepted after a solid and strategic process of diplomacy and argumentation and should be built in on all lines of state institutions (H. M Said Nisar, 2008: 302), so that the national interest (in this case is sustainable development) can be realized through an international forum related to the loan agreement of the Government of Indonesia.

\section{E. CLOSING}

From the discussion, some conclusions can be drawn as follows:

1. The status and legal status of the government's loan agreements has not yet shown clarity and regularity. This can be seen either from a practical perspective regarding the legal status of the loan agreement or from its 
regulation in national law. In accordance with Law Number 24 of 2000 on International Agreements, the loan agreement in Article 10 letter (e) is an agreement characterized as an international agreement, while in practice the government loan agreement has been subject to the private or civil (international). It is imperative that immediate amendments must be made so that the aspect of the international treaty that forms part of the Indonesian state administration may reveal its status and position in the national legal system. In addition, the loan agreement of the government is a policy action (politics) of the government in the state financial arrangements that aim to complement capital in realizing national development.

2. Whereas economic growth as a basic aspect of national development should still be sought continuously. But the use of capital from foreign debt should be reviewed. However it is also important to examine that the state in making the loan agreement has the capacity as a public legal entity (iure imperii) because it carries the interests of the nation and state. It is thus important to make legal politics reforms related to the government's loan agreements. Legal politics speaks at the function of empirical and political level of law in terms of ethics and techniques of law-making activities and at the same time as a form of legal discovery, and it is directed to see to what extent the established law has use value, including the ideological and political aspect. Good legal politics has an important role, not only to realize sustainable development but also to the sustainable mindset of society, where society is both the subject and the object of development itself. Concerning the legal policy towards government foreign loan agreements that have been more inclined to use private or civil law system, in its implementation it gives less value to the national interest of Indonesia. Above all, the important thing is how the Indonesian government reduces its dependence on foreign loan or debt by increasing national savings, promoting exports and increasing national income.

\section{BIBLIOGRAPHY:}

Books:

Adrian Sutedi, 2010, Hukum Keuangan Negara (Law of State Finance), Sinar Grafika: Jakarta.

Besson Samantha and Tasioulas John, 2010, The Philosphy of International Law, , Oxford University Press: New York. 
Damos Dumoli Agusman, 2010, Hukum Perjanjian Internasional Kajian Teori dan Praktik Indonesia (Law on Treaty: Theory and Practice in Indonesia), Refika Aditama: Bandung.

, 2008, Perjanjian Internasional Dalam Teori dan Praktik di Indonesia Kompilasi Permasalahan (Law on Treaty: Theory and Practice in Indonesia), Direktorat Perjanjian Ekonomi dan Budaya; Jakarta: Direktorat Jenderal Hukum dan Hubungan Luar negeri. Kementerian Luar Negeri Indonesia.

Eddy Pratomo, 2011, Hukum Perjanjian Internasional (Pengertian, Status Hukum, Dan Ratifikasi) (Law of treaty: Definition of Legal Status and ratification), Alumni: Bandung.

Friedman Wolfgang, 1953, Legal Theory (3th edition), Steven and Sons LTd: London.

Hata, 2006, Hukum Perdagangan Internasional Dalam Sistem GATT dan WTO (International trade Law in The System of GATT and WTO), Refika Aditama: Bandung.

Huala Adolf, 2011, Hukum Ekonomi Internasional (International Economic Law), cetakan kelima, Keni Media: Bandung. , 2010, Dasar-Dasar Hukum Kontrak Internasional (edisi revisi) (Principle of International Contract Law), Refika Aditama: Bandung.

H.M Said Nisar, 2008, Kajian Hukum Internasional Dari Segi Kepentingan Nasional (Refleksi Dinamikan Rangkaian Pemikiran Dalam Dekade Terakhir, Didedikasikan untuk Tokoh Hukum Prof Dr. Komar Kantaatmadja, SH, LL.M), Jakarta, Perum Percetakan Negara.

Iman Syaukani, A Ahsin Thohari, 2010, Dasar-Dasar Politik Hukum (Principle of The Politics of Law), cetakan ke-6 Jakarta, RajaGrafindo Persada.

Mochtar Kusumaatmadja, 2006, Konsep-Konsep Hukum Dalam Pembangunan (Concepts of Law in the Development), Alumni: Bandung.

Muhammad Djafar Saidi, 2008, Hukum Keuangan Negara (Law of State Finance), RajaGrafindo Persada: Jakarta.

Otje Salman dan Anthon F Susanto, 2009, Kapita Selekta Hukum; Tinjauan Kritis atas Perkembangan Hukum seiring Perkembangan Masyarakat di Indonesia,sering Perkembangan Masyarakat Nasional dan Internasional, Widya Padjadjaran; Bandung

Schrivjer Nico dan Weiss Fiedl, 2004, International Law and Sustanable Development ;Principles and Practice, Leiden, The Netherlands,Martinus Nijhoff Publishers.

Sudikno Mertokusumo, 2010, Penemuan Hukum (Finding Law), Cetakan kelima, Univ. Atma Jaya Press; Yogyakarta. 
Sri Setianingsih Suwardi, 1995, Aspek hukum Perjanjian Pinjaman (loan Agreement) Antara Republik Indonesia dan Bank Dunia Serta Penerapannya Kedalam Hukum Nasional Indonesia, Disertasi , Program Pascasarjana, Unpad: Bandung.

Syahmin AK, 2006, Hukum Kontrak Internasional (International Contract Law), Raja Grafindo Persada: Jakarta.

Trubek M. David, et.al, 2006, The New Law and Economic Development;A Critical Appraisal, Cambridge University Press; Edinburg UK.

Yudha Bhakti, 2012, Penemuan Hukum Suatu Proses Memahami Ajaran Sumber Hukum (Catatan Pidato Purnabakti 70 Tahun Prof. Dr H, Yudha Bhakti Ardhiwisastra, SH, MH), Bandung, Fakultas Hukum Universitas Padjadjaran, , 1999, Imunitas Kedaulatan Negara, Di Forum Pengadilan Asing, Alumni: Bandung.

\section{Journals and Papers:}

Abdul Hakim Garuda Nusantara, "Politik Hukum Nasional" makalah pada Kerja Latihan Bantuan Hukum, LBH Surabaya, September 1985;

Atip Latipulhayat,.( Khazanah Mochtar Kusumaatmadja),Padjadjaran, Jurnal Ilmu Hukum, Vol.I Number3. Des 2014;

Daud Silalahi, Perkembangan Hukum Lingkungan Internasional, (paper) disampaikan pada Seminar Nasional Perkembangan Materi Pengajaran Hukum Lingkungan, FH Unpad, 13 Oktober 2014;

Koesnadi Hardjasoemantri, Good Governance Dalam Pembangunan Berkelanjutan Di Indonesia; (Seminar Pembangunan Hukum Nasional VIII) Bali, Juli 2003;

Sjahrudin Rasul, Manajemen dan Pengawasan (Bahan kuliah), Fakultas Hukum Pascasarjana Universitas Padjadjaran, 2011;

Williams Marc, Aid Sustainable Development and The Environmetal Crisis, International Journal of Peace Studies

Himpunan Naskah Perjanjian Internasional Yang Telah Ditandatangani Oleh Pemerintah RI Vol I, Number2001.1.2001 Tahun 2001 Periode Januari-Desember, Dirjenn Ekososbud Departemen Luar Negeri;

Document Compilation of The International Treaties (Compilation of International Agreement Manuscript registered at Economic and socio-Cultural Agreement Room, Directorate General of Law and International Agreement of the Ministry of Foreign Affairs) 2008;

Analisis Kebijakan Pemanfaatan Pinjaman Luar Negeri Pemerintah; Kementerian Perencanaan Pembangunan Nasional/Badan Perencanaan Pembangunan Nasional, Desember 2015; 
Profil Utang dan Penjaminan Pemerintah Pusat Edisi April 2017 Direktorat Penglolaan Pembiayaan dan Resiko Kementerian Keuangan Republik Indonesia;

\section{Regulations:}

The 1945 Constitution of the Republic of Indonesia (the Fourth Amendment);

Law Number 24 of 2000 regarding International Agreements;

Law Number 23 of 2007 regarding State Finances

Law Number 25 of 2004 regarding National Development Planning System;

Law Number 17 of 2007 regarding National Long-term Development Plan 2005-2025;

Law Number 37 of 1999 regarding Foreign Relations;

Government Regulation Number 10 of 2011 regarding Procedures of Procurement of Foreign Loans and Acceptance of Grants;

Vienna Convention On The Law of the Treaties Year 1969. 